\title{
特集号の論文募集
}

\section{「有機誘電性・機能性材料の作製・物性評価技術の 新展開と次世代エレクトロニクスへの応用」特集}

電気学会論文誌 A（基礎・材料・共通部門）では，有機材料を中 心とした次世代エレクトロニクス技術の応用展開を目指した最新 動向を把握することを目的として, 平成 28 年 11 月号に「有機誘電 性・機能性材料の作製・物性評価技術の新展開と次世代エレクトロ ニクスーの応用」と題した論文特集号を企画しました。

有機材料の電子光機能とその工学的応用に関連した国際会議が 国内外で多数開催されている。「アジア地区における有機誘電性・ 機能性電気電子材料の次世代エレクトロニクスへの応用」に関する 調查専門委員会（委員長 岩本光正・東工大）では，前調查専門委 員会 (アジア地区における有機誘電体・導電性電気電子材料研究の 最前線）の活動を基盤として, 有機誘電性・機能性電気電子材料の 趨勢と次世代エレクトロニクスへの応用に関寸る調査や研究交流 活動を継続している。これまでの活動を通じて得られたこの分野の 最先端の研究動向や新技術を紹介し, あわせてこの分野に関心のあ る研究者の推進する研究の新展開を特集論文としてまとめること は, 電気工学分野の展開にとって重要かつタイムリーと考えられ る。

\section{論文を募集する技術分野}

・有機電気電子材料の界面物性・作製・評価技術の新展開
・有機電気電子材料の誘電性・機能性および電気・光現象

・ソフトマテリアルの界面物理・評価技術とエレクトロニクス 応用

・有機ナノ界面制御素子の新展開

・有機エレクトロニクス関連素子（有機 FET，有機 EL，有機 太陽電池など)

・バイオエレクトロニクス関連技術（バイオセンサ，センシング システムなどバイオミメティックな素子応用を含む)

掲 載 号 平成 28 年 11 月号

投稿締切 平成 28 年 1 月 29 日（金）

刷上り 6 頁程度, 和文または英文, レター (刷上り 2 頁) も可。詳細は論文投稿の手引きに従ってください。

投稿方法 電子投稿・查読システムの「論文投稿画面」で特集テー マ『「有機誘電性・機能性材料の作製・物性評価技術の 新展開と次世代エレクトロニクスへの応用」特集号』を 選択してください。

投稿手引/投稿先 URL http://www.iee.jp/?page_id $=642$

ゲストエディタ/問合せ先

小野田光宜

兵庫県立大学 大学院工学研究科 電気物性工学専攻

厂 671-2280 兵庫県姫路市書写 2167

Tel/Fax 079-267-4860

E-mail : ss-syu02@eng.u-hyogo.ac.jp 